\title{
蒸発冷却機能を持つ孔あきレンガ壁体により形成される 微気候の予測に関する研究
}

\section{STUDY ON PREDICTION OF MICRO-CLIMATE FORMED BY A PASSIVE COOLING WALL MADE OF VENTILABLE BRICKS WITH EVAPORATIVE COOLING EFFECT}

\author{
小栗 健*, 梅干野 昆**, 白井一義***, 奥田知 康**** \\ Ken OGURI, Akira HOYANO, Kazuyoshi SHIRAI \\ and Tomoyasu OKUDA
}

\begin{abstract}
A product of "passive cooling wall (PCW)" system has been developed and evaluated its cooling effect. The system consists of water-permeable ventilable bricks with evaporative cooling effect to offer a comfortable spot at the outdoor and semioutdoor space. Knowing the micro-climate around the setting area of the system, the predicable method of cooling effect at the planning is necessary to make the system practical. A analytical model based on the ( $\mathrm{k}-\varepsilon$ )turbulence model is used to verify the availability of this predicable method. A correlation between the date of calculation and experiment was examined in comparison with the data of average of temperature, humidity and velocity. The tendency of distribution of temperature and humidity was good corresponded on the whole, except for velocity.
\end{abstract}

Keywords: passive cooling, evaporative cooling, ventilable brick, outdoor and semi-outdoor, ventilation, numerical simulation

パッシブクーリング、蒸発冷却、孔あきレンガ、屋外・半屋外空間、通風、数值計算

\section{1.はじめに}

近年、都市部を中心とした夏季熱環境の悪化が様々な形で報じら れており、屋外・半屋外空間で快適に過ごすことが困難な状況にな りつつあると考えられる。このような状況から、著者らは屋外・半 屋外空間に自然エネルギーを利用して快適環境を形成するために 透水性孔あきレンガを用いた蒸発冷却壁体 (以下 P C W) を開発し、 屋外・半屋外空間における冷却効果の評価を行ってきた1)，2)。P $\mathrm{CW}$ 冷却効果は周辺の微気候、とりわけ外部風の風向風速、気温、 湿度等に影響されることが明らかになっており、実際に建築空間へ 適用する場合には設計段階で外部の微気候を十分に把握し、P CW の配置構成による冷却効果の現れ方を予測できる手法の開発が望 まれる。

P CWのような熱・水分エネルギー収支を組み込んだ乱流モデル については多くの研究事例があり、例えば、吉田、村上らの「対流・ 放射・湿気連成解析手法」が、 $\mathrm{k}-\varepsilon$ モデルベースの精緻なものと して確立されている3゙。しかし、これらの手法が、P CWのような 蒸発冷却を伴った孔あき壁体によって形成される流れ場を対象に 検討されたことはなく、その適用に関しては興味深い。

このような状況から、本研究では既往の主要な解析モデル及び計 算手法を用いて、どの程度 P C Wにより形成される微気候が再現で
きるのか検討することとした。

ただし、既往の予測手法そのものの精度を発展させることに目的 をおいているわけではなく、環境設計のレベルで有効となり得る程 度の情報、すなわち、P CWにより形成される気候分布を、現存す る手法を活用して予測できるか否かを検討するものである。その 際、解析モデルについては、抵抗物体としてのP C Wの扱いを工夫 してモデル化する。

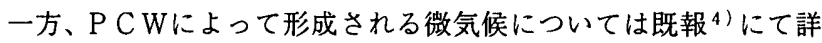
細に解析しており、ある一定条件の風が吹くような定常的な状況以 外の非定常な条件下で大変興味深い知見が得られており、気温や風 速などの「ゆらぎ」が「涼しさ」を感じさせる一要因になっている ことを確認している。しかし、設計支援を目的とした予測をすると すれば、まずは認知されている予測手法を利用し、かつ定常状態を 扱うことが妥当であり、また、一定方位の風向に対して形成される 微気候を予測できることも有用になるという考えに達した。

本報では、そのような背景から、既往のモデルとして、1)澍木廷 りの気流解析である程度認知されている平岡ら5)のモデルによる 予測手法を採用し、2) P CWに特有の抵抗係数（圧力損失）、対流 熱伝達等については風洞実験で求めた值を利用してシミュレーシ ヨンを行った。3)一方で、実測により P C W廻りの微気候の把握を

\footnotetext{
* INAX 技術統括部空間デザイン研究所

** 東京工業大学大学院総合理工学研究科 教授 $\cdot$ 工博

*** 太平洋セメント 博士(工学)

**** 山下設計
}

Space Design R\&D Center, INAX Corporation

Prof., Tokyo Institute of Technology, Dr. Eng.

Taiheiyo Cement Corporation, Dr. Eng.

Yamashita Sekkei 
行うと共に一定方位の風向で風速も安定した状況でのデータを敬 理し、4)予測結果と実測結果とを比較してそれらの特徽の差異につ いて考察した。

\section{Z。解行そジル}

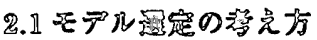

前章で述べたように、P C Wによって形成される徽気候の特徽に は「ゆらぎ」が挙げられるが、この「ゆらぎ」のような変動周期の 短い非定常的な現象を扱う予測手法としては、乱流モデルとしてL E S などの適用が考えられる。L E S は一般に計算格子を十分に小 さく取ることにより高精度で信頼の高い予測が期待できるが、細か い差分格子間隔を必要とすることから膨大な記憶容量と長い計算 時間が必要となり、経済性の面ではかなり劣ると考えられる。

一方、設計支援のレベルでは、現状認知されている解析モデルを 利用して定常状態における予測を行うことが妥当であると考え、一 定方位の風向に対して形成される気候分布を予測できることが環 境設計の初期段階で有用な情報になると考えた。

このような定常状態を扱う乱流モデルとして広く利用されてい

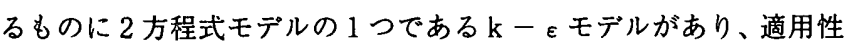
の広さ、経済性、信頼性などの点でバランスが良いと考えられる。

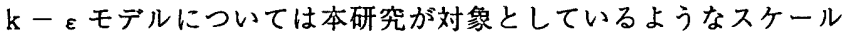
での綪緻な熱環境把握には、乱流エネルギー $\mathrm{k}$ 、浮力項、潜熱エネ ルギー、あるいは壁面近傍での精緻な物理現象の扱いから、吉田, 村上らのモデル3)、村上, 加藤らのモデル6)、平岡らのモデル5)， 7)など様々な研究事例があるが、モデル選定にあたっては、P C W の組み合わせなど設計への効率的な反映に適した手法であること やP C W と熲似した流れ場を対象に開発されたものであることな どを考虑した。

ここで、P C Wの流れ場が、(1)外部空気はレンガの孔を通過する 際に水の蒸発による㷫伝達、すなわち熱・我分同時移動が行われ冷 却される、(2)外部㞬気はレンガの有するスリット状の孔を通過す る、ことにより形成されるため、植物群落内の気流性状と比較的近 いものと考えられる。このような植物群落内の気流性状を予測する 手法として主なものが、葉を抵抗物体として圧力損失項を各種方程 式に組み込んだ平岡らの手法 ${ }^{51}$ ，7)であり、既に樹木廻りの気流解 析である程度の実綵を上げていることから、今回は本モデルを探用 することとした。

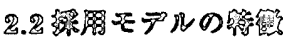

設計凟撛としてP C Wが形成する微気候を捉える場合、各レンガ の孔の形状までを再現するように差分格子を分解し、境界条件をた てて解くことは膨大な計算負荷を必要とするため現実的な手法と しては適切でなく、孔あきレンガをセル体穦内にある抵抗物体と見 なす方が賢明であると考えられる。この様な抵抗物体のモデル化と しては、植物群落内及び都市キャノピー内に乱流モデルとして $\mathrm{k}$ $\varepsilon 2$ 方程式モデルを用いた平岡らの方法 ${ }^{51}$,7) があり、運動方程式 に抵抗物体による抵抗力項を付加し、乱流エネルギー及び乱流散逸 の翰送方程式に抵抗物体による生成項を付加することでモデル化 が行われている。いずれのモデルも運動方程式に抵抗物体による抵 抗力項を付加し、乱流エネルギー及び乱流散逸の翰送方程式に抵抗 物体による生成項を付加することでモデル化が行われている。しか
し、乱流散逸の生成項が文献 5 )では風速の 3 垂に比例する形である が、文献7では物体によって作りだされる渦の特徵長さにより与え られていることや、文献りでは定式化の際、有効体積率がみられな いが、文献7)では現れているなどの違いがある。この有効体積率は 抵抗物体内もしくはそのごく近傍の流速に影響すると考えられる ものである。

本研究では、初期段階での環境設計資料として、熱的観点から重 要になると考えられる、㞬間全体の風速分布（平均風速）、温度分 布、湿度分布を把握することを優先し、P C Wのごく近傍に形成さ れる微気候を把握することは対象外とする。従って、本研究では文 献 5)で平岡らにより提案されている $\mathrm{k}-\varepsilon 2$ 方程式モデルをもと に、P CWによる抵抗、冷却及び蒸発という機能を組み込んだ解析 モデルを作成し、SIMPLE 解法と呼ばれる定常流れを効率的に解く 方法を導入して予測を試みた。

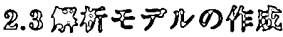

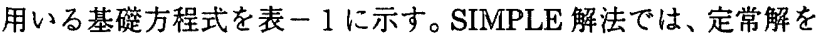
求めるため時間幅を無限大にとって非定常項を省略し、その無限大 の時刻において陰的解法で赤知数を求めるように定式化されてい る。よって、各翰送方程式は非定常項の省略された形となる。各方 程式の下線を引いた項を P C W部分のセルで計算する。

\section{表一 1 基䂠方程式}

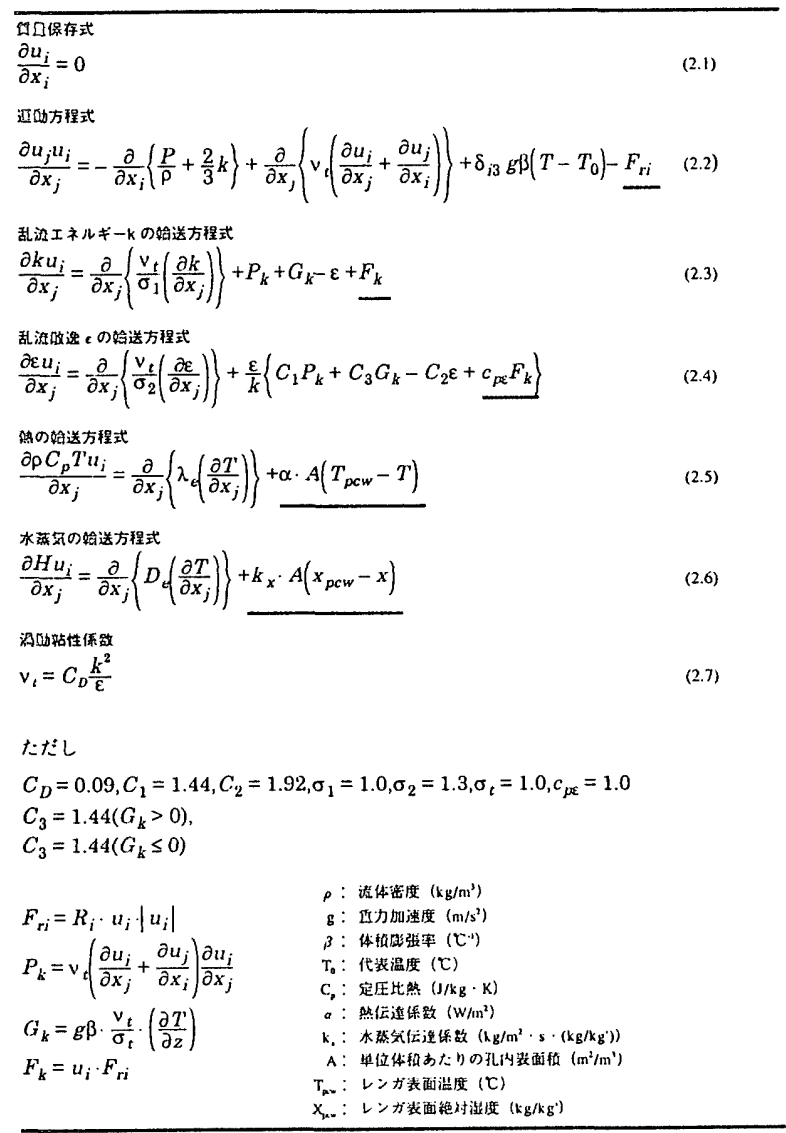

下線部分は P C W部分のセルにて計算を行う 


\section{(1)運動方程式}

運動方程式は（2.2）式のように、 $\mathrm{PCW}$ 部分のセルで風速の 2 乗に比例する抵抗力項が付加される。抵抗係数の設定にあたって は、本来 P CWにあたった風は孔あき流通方向以外にも流れていく ためその影響を考慮すべきであるが、完全な無孔の壁にあたった場 合に比べ、P C Wの場合は風が孔あき流通方向に流れていくため比 較的その影響は小さいものと考える。従って、ここでは孔あき流通 方向のみの抵抗係数を考慮するものとした。抵抗係数 Riについて は、次節の通気実験により決定する。

(2)乱流エネルギー $\mathrm{k}$ の輸送方程式

乱流エネルギー $\mathrm{k}$ の輸送方程式は（2.3）式のようになる。 P C $\mathrm{W}$ 部分のセルで風速の 3 乗に比例する生成項が付加される。

(3)乱流散逸 $\varepsilon$ の輸送方程式

乱流散逸 $\varepsilon$ の輸送方程式 (2.4) 式は、乱流エネルギー $\mathrm{k}$ と同様 に P C W 部分のセルで風速の 3 乗に比例する生成項が付加される。 (4)熱の輸送方程式

熱の輸送方程式 (2.5) 式は、P C W 部分でレンガ表面温度 T pcw と流体温度 $\mathrm{T}$ との温度差と熱伝達係数 $\alpha$ 及び単位体積あたりの孔 内表面積 Aにより算出される。単位体積あたりの孔表面積 $\mathrm{A}$ は、ス リット型では $66.0 \mathrm{~m}^{2} / \mathrm{m}^{3}$ 、開口型では $30.2 \mathrm{~m}^{2} / \mathrm{m}^{3}$ である。レンガ表 面からの熱伝達係数 $\alpha$ は次節の通気実験により風速の関数として 与える。

また、熱に関しては、運動方程式、 $\mathrm{k}, \varepsilon$ の輸送方程式に温度差 による浮力の扱いとして Viollet 型モデルを組み込んでいる。

(5)水蒸気の輸送方程式

水蒸気の輸送方程式 (2.6) 式は、P C W 部分でレンガ表面絶対 湿度 X ${ }_{\mathrm{pcw}}$ と流体絶対湿度との差と水蒸気伝達係数 $\mathrm{k} \times$ 及び単位体 積あたりの孔内表面積 $\mathrm{A} に よ り$ 算出される。

レンガ表面からの水蒸気伝達係数 $\mathrm{k} \times \mathrm{x}$ は、ルイスのアナロジーを用 いて次式により熱伝達係数 $\alpha$ より算出する。

$$
\begin{aligned}
& k_{x}=\frac{\alpha}{C_{p m}} \\
& C_{p m}{ }^{m} C_{p a}+C_{p v} \times[J / k g \cdot k] \\
& \text { ただし、C }{ }_{p a}: \text { 乾燥空気の定圧比熱 }=1004.6(\mathrm{~J} / \mathrm{kg} \cdot \mathrm{K}) \\
& C_{p v}: \text { 水蒸気の定圧比熱 }=1846.0(\mathrm{~J} / \mathrm{kg} \cdot \mathrm{K})
\end{aligned}
$$

\section{4 通気実驗による孔あきレンガの抵抗保数及び焦伝達保数 \\ 2.4.1 通気実䮦の概要}

抵抗係数 $\mathrm{R}$; 及びレンガ表面からの熱伝達係数 $\alpha$ は簡易風洞を用 いた通気実験により求めた。ここで、P C Wを利用する一般的な空 間形態として、主風向側にP CW、その両端には断熱に優れた壁が 存在し、日射遮蔽のための屋根および床により構成されていること を想定した。従って、PCWに導入される気流は、孔あきレンガの 流通方向が主に解析の対象となる。また、P C W 部分での圧損によ る平均流の減衰はあるものの、 P C W 端部での風速の変化は無穴の 壁面に比べか小さくなるものと考え、実験装置を便宜的に与えた。

実験装置を図一1に示す。風洞壁面の影響を小さくするためにレ ンガを 3 段に重ね、中段レンガの中央通気孔を通る中心軸線上でレ ンガ前後の圧力損失及び各点の温度、風速を測定した。温度はヤ熱 電対を用いて測定し、压力損失は隔膜式差圧計を用い、風洞にチュ
ーブを垂直に挿入して測定した。また、風速の測定は通気孔出口と 風下においてサーミス夕風速計を用いて行った。

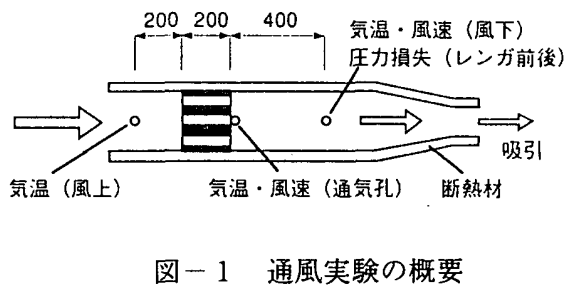

\subsection{2 抵抗保数の決定}

抵抗係数 Ri はレンガ前後での圧力損失により決定される。実在 空間では前後の気流性状による通気孔内への影響も考えられるが、 ここでは単純化して通気孔内の気流は一意に定まるものとし、孔内 風速に相応する通気抵抗の結果として圧力損失を考えるものとす る。圧力損失の測定は乾燥レンガを用い、通気風速を逐次変えて行 った。図ー 2 にレンガ孔内平均風速と圧力損失の関係を示す。圧力 損失は孔内風速の 2 乗に比例する関数として与えられ、その比例定 数が抵抗係数 $\mathrm{R}_{\mathrm{i}}$ となる。よって、実験結果から圧力損失を孔内風 速の 2 乗に比例する関数として近似し、スリット型の抵抗係数 1.01、開口型の抵抗係数 0.74 を得た。

\subsection{3 焦伝连保数の決定}

温度測定は、気温 $32^{\circ} \mathrm{C}$ 、湿度 $60 \%$ の環境制御室内において、レ ンガを気温に等しい水中で飽和させた後、風洞に設置して一定通気 のもとで行った。風下気温は孔内風速による違いはあるが、通気開 始後数分から 1 時間で定常に達した。通気孔入口温度を $T_{i}$ 、通気 孔出口温度を T pcw、通気孔内平均対流熱伝達率を $\alpha$ 、通気孔内平 均風速を $\mathrm{u}$ として次式のような関係が成り立つ2)。

$$
\frac{T_{i}-T_{0}}{T_{1}-T_{p c w}}=1-\exp \left(\frac{\alpha \cdot 2(a+b) L}{C_{p} \rho a b u}\right)
$$

ただし

$\mathrm{a}, \mathrm{b}$ : 通気孔断面の各辺の長さ (m)

$\mathrm{L}:$ 通気孔長さ $(\mathrm{m})$

$\mathrm{C}_{\mathrm{p}}$ : 空気の比熱 $(\mathrm{J} / \mathrm{kg} \cdot \mathrm{K})$

$\rho:$ 空気の密度 $\left(\mathrm{kg} / \mathrm{m}^{3}\right)$

ここで、レンガ表面が完全飽和である場合は、熱伝達と物質伝達 のアナロジーにより T pcw は外気湿球温度と等しいと見なすことが でき、（2.10）式の左辺は外気乾湿球温度差に対する冷却効率とな る。（2.10）式を $\alpha$ について解くと次式が導かれる。

$$
\alpha=-\frac{C_{p} \rho a b u}{2(a+b) L} \cdot \ln \left(1-\frac{T_{i}-T_{0}}{T_{i}-T_{p c w}}\right)
$$

風上気温と通気孔出口気温及び通気孔出口風速の測定值から、 （2.11）式により通気孔内平均対流熱伝達率 $\alpha$ を算出した。

図-3に孔内風速と熱伝達係数の関係を示す。この実験結果から 熱伝達係数 $\alpha$ を孔内風速の一次関数で与えることとし、次式により 算出する。

$$
\begin{array}{ll}
\text { スリット型： } & \alpha=6.17 \mathrm{u}+8.40 \\
\text { 開 ロ 型: } & \alpha=7.44 \mathrm{u}+5.31
\end{array}
$$




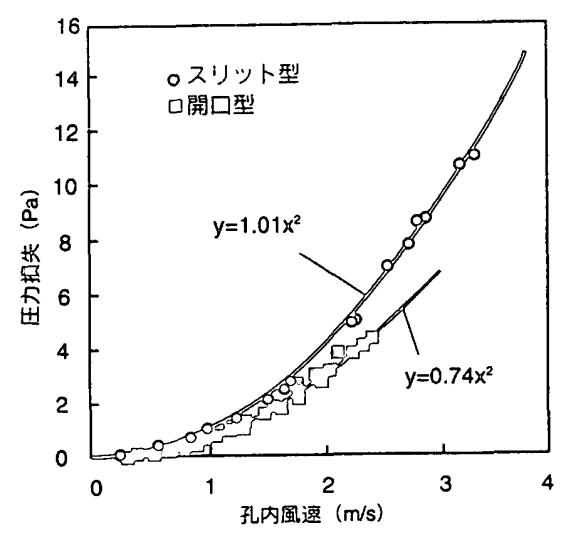

図一 2 孔内風速と差圧の関係

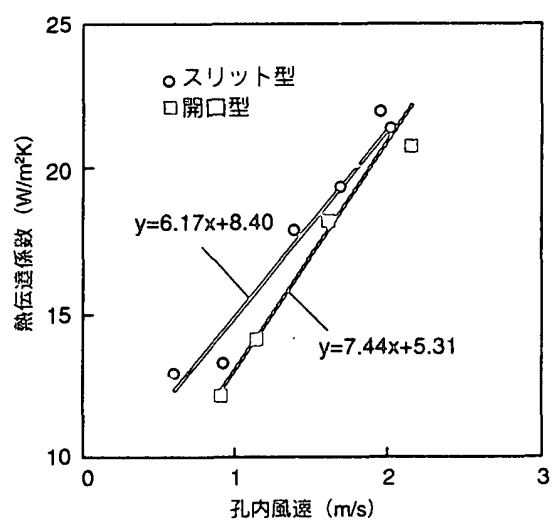

図一 3 孔内風速と熱伝達係数の関係

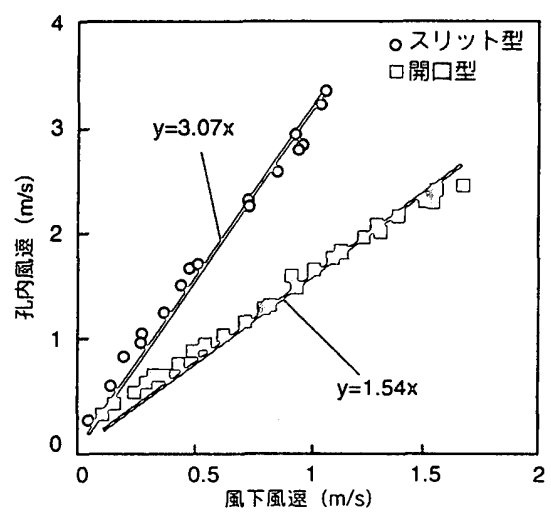

図一 4 孔内風速と風下風速の関

\subsection{4. 国䞨の络正}

解析モデルは研究の目的から有効体稳率を含めていないが、この 有効体積率は抵抗物体部分の風速に影響するもので、外部風がセル 内の P C Wを通過する際にレンガ孔内の風速の上昇を再現するも のであるため、本モデルではレンガ孔内の風速上昇が再現されない ことになる。一方、(2.2)式における P C W部分の抵抗力項 F ri 熱 伝達係数 $\alpha$ の算出式は、レンガ孔内平均風速の関数となっているた め、計算を行う際にはセル体積内の P C W 部分の風速を孔内風速に 補正して算出する必要がある。

従って、風洞実験により孔内風速と風下風速との関係を求め、解 析モデルに適用可能な P C W 部分の風速補正式を決定する。図一 4 に孔内風速と風下風速の関係を示す。この関係から、 $\mathrm{P} \mathrm{CW}$ 部分の 抵抗力項 $\mathrm{F}$ ri と熱伝達係数 $\alpha$ を算出する際の孔内風速は、次式によ り補正したものを用いる。

スリット型：孔内風速 $=3.07 \mathrm{u}$

開 口 型：孔内風速 $=1.54 \mathrm{u}$

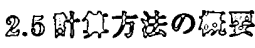

\section{2.も.1管分化の方}

本研究では、予測計算にあたり SIMPLE 解法を用いた定常計算を 行う。各方程式はスタッガード格子に定義される。各翰送方程式の 空間差分にはハイブリッド法を用いる。

2.5.2 的等の游行

予測計算の流れを図－ 5 に示す。先ず、（2.1）式〜（2.4）式に より風速・乱流エネルギー・乱流散逸の計算を行う。結果が収束後、 収束した解を初期值として（2.1）式一（2.5）式により温度と気流 の連成計算を行うことで、風速と気温の解を求める。その後、水蒸 気量による気流への影響は無いと仮定して、気流の計算結果を用い て水蒸気の翰送方程式（2.6）式のみを別に解く。

なお、各方程式の収束判定は、前ステップとの誤差の解析空間全 体での平均値で行い、その值が全物理量で 10.6 以下となった時を収 束とした。

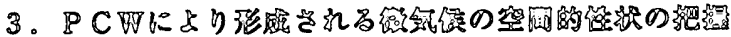

P CWの組み合わせによって形成される微気候の空間的な性状 を把握するため、屋外実験により温度、湿度、風速の実測を行った。 ここで、P CWにより形成される微気候は時間的に変動するもので
あるが、このような非定常な現象については $2.1 て ゙$ て述べたように本 研究の対象とせず、まずは実験空間内の微気候の空間的性状を把 握・分析し、その結果から空間全体の特徵を把握するための代表的 な測定点を選定し、これらの点について温度、湿度、風向の定点測 定を行った。

また、実測結果の内、風向・風速が比較的安定していた期間を抽 出し、温度、湿度および風速を平均化した值を用いて解析モデルの 計算結里との比較を行い、本解析モデルが P C Wの微気候を予測す る手法として適用できる可能性があるかを検討することとした。

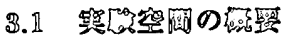

実験は十分な屋外風速が得られる開放空間として、東京工業大学 長津田キャンパス内にある 2 階建て R C 造の建物屋上で行い、実験 空間を図一 6 に示すように配置した。実験場はおよそ南北 $10 \mathrm{~m}$ 、 東西 $25 \mathrm{~m}$ の長方形の広場で、周囲には高さ約 $1.2 \mathrm{~m}$ の R C 造の手 摺りがある。実験空間は、P C Wに囲まれ温度が低下する部分と、 外気が抜けて温度が高くなる部分を形成するよう考虑し、高さ約 $1.8 \mathrm{~m}$ の 6 体の P C Wユニット（開口型 4 体、スリット型 2 体）及 び 2 面の壁面（木造・ポリスチレンボード貼り）を用いて約 $3 \mathrm{~m} \times$ $3 \mathrm{~m}$ の空間を形成した。また、実験空間には日射遮蔽用の白色ウレ タンシートの屋根をP CWの上端にほほ合わせてかけた。実験空間

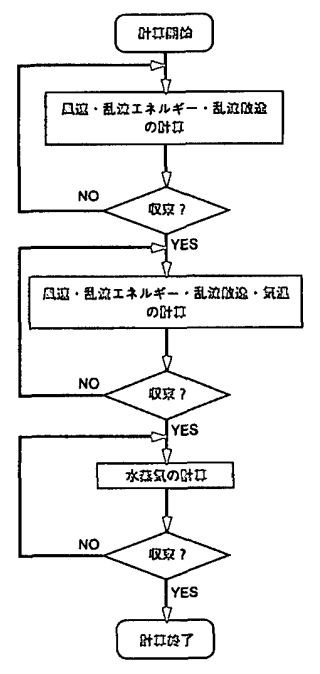

図一 5 計算の流れ図 の外観を図ー7に示す。なお、以降、 本論文では、図ー6に示したように実 験空間内のスリット型P CWを $\mathrm{s} 1$ ～2, 開口型を。 $1 \sim 4$ と呼ぶこと にする。

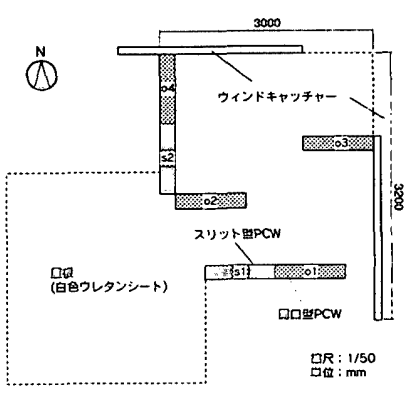

図一 6 実験空間の概要 


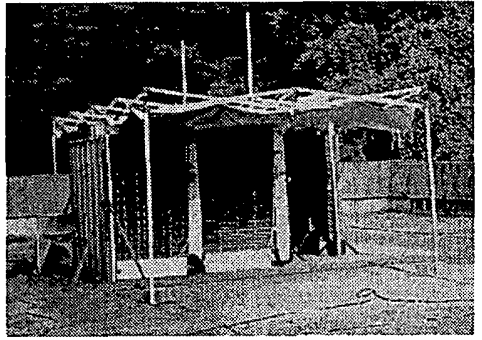

図一7 実験空間の外観

\section{2 徽気侯の空間分布}

著者らにより開発された 3 次元位置測定装置注1)を用いて、実験 空間内の微気候を計測し、空間分布の把握・分析を行った。測定は 実験空間の全体を捉えるよう高さ $1.0 \mathrm{~m}$ の位置で網羅的に行い、空 間内の任意の点について温度、湿度、風速を 2 秒間隔で 10 分間測 定した。ここで、外部気候の変化が大きい場合、空間内の微気候の 分布を正しく把握することはできないため、外部条件が比較的安定 していることが重要である。従って、外部気候条件が安定していた 1997.9.7のデータについて分析を行った。測定中の外気平均温度は $30.1^{\circ} \mathrm{C} 、$ 湿度は $71.4 \%$ 、外部風向はほほ南西であった。

(1)水平面気温分布

空間内の水平面温度分布を図 -8 (a)に示す。南西及び北東の開 口部で高温部分が分布している。s 2 ，。2 で囲まれた部分及び南 側のs $1 ， 01$ の近傍では低温部分が見られ、特にs 2 ，。2近傍 では気温の低下がよく現れている。

(2)水平面湿度分布

水平面湿度分布を図一 8 (b)に示す。気温の低下した部分は湿度も 上昇しており、P C Wから蒸発した冷気魂が微気候を形成している ことが示されている。

(3)水平面風速分布

空間内水平面風速分布を図 -8 (c)に示す。南西の開口部および 北側の壁面近傍での風速增加が顕著である。南西の開口部からの外 気の流入および北側壁面の張り出し効果による。4を通しての通 風が得られていると考えられる。

\section{3 実䀦空間内の定点測定の概要}

3.2 の結果を参考にして空間内を網羅的に把握するよう図ー9に 示すような定点測定の位置を設定した。ここで、空間内の各壁面近 傍の分布を細かく把握するため、次の 4 種類の測定条件を設定して 行った。(a)測定 1 は空間全体の分布を測定、(b)測定 2 は南西側開 口部の高温部分から $\mathrm{s} 2,02$ に囲まれた気温の低下する部分を測 定、(c)測定 3 は s 2，０２に囲まれた気温の低下する部分から北東 の開口部分を測定、(d)測定 4 は各P CWの近傍 $10 \mathrm{~cm}$ を測定するも のである。

気温は T熱電対 $(0.1 \mathrm{~mm}$ 線) を用いて高さ $1.0 \mathrm{~m}$ と $0.3 \mathrm{~m} の 2$ 点 で測定し、鉛直方向の測定も含め計 18 点の測定とした。また、湿 度、風速は各測定毎に測定点を選定して行った。外部気候について は、乾湿球温度は通風式白金抵抗乾湿計により測定し、風向・風速 は超音波風速計により測定した（表一2）。

測定は夏季の晴天日の 4 日間で行い、気温が高く比較的風速が強 い時間帯である正午から午後 4 時の間で各測定を 1 時間〜 2 時間 毎に行った。なお、測定間隔は、温度および風速については 2 秒間 隔、湿度については 5 秒間隔である。

\section{4 比数用データの抽出}

今回用いた解析モデルが P C Wの微気候を予測するモデルとし て適用可能かどうかを検討するため、3.3で得られた定点測定の実 験データの中で、外部の風向が南から西の間で安定しており、風速 も比較的強い期間を抽出し、その期間の測定デー夕を平均化するこ とで比較検討のためのデータを作成した。抽出したデータケースの 外気象条件を表一 3 に示す。各測定毎に風速が強い場合と弱い場合 の 2 種類抽出した 8 ケースであり、平均化にあたって温度および風 速については 2 秒間隔、湿度については 5 秒間隔で測定したデータ （以降、単に実験值と称す）を各期間で平均化した。

例として、図一10にケース 1-2の実験値を示す。s 2、o 2 にL 字に囲まれた部分の気温の低下、湿度の上昇というＰＣWの蒸発冷 却効果による微気候の形成状況が確認できる。また、南西側開口部 で気温が高く、外気の流入の影響が現れていることが分かる。北東 側の開口部では若干風速が強くなっている様子も確認できる。

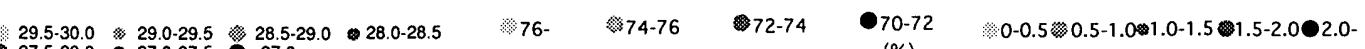

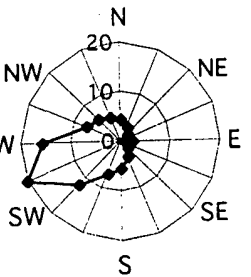

移動測定時の風配図

移動測定時の風配図

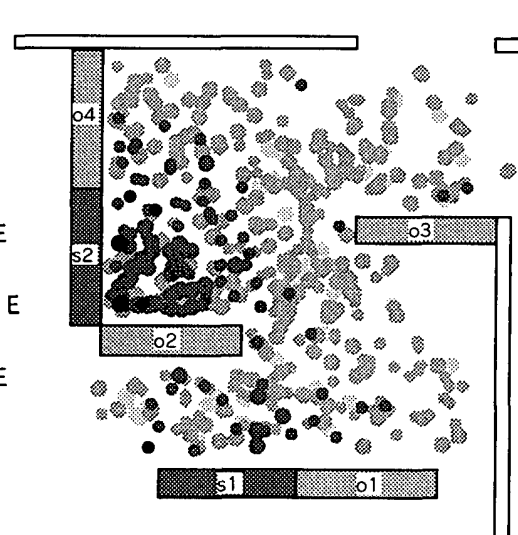

(a) 気温分布

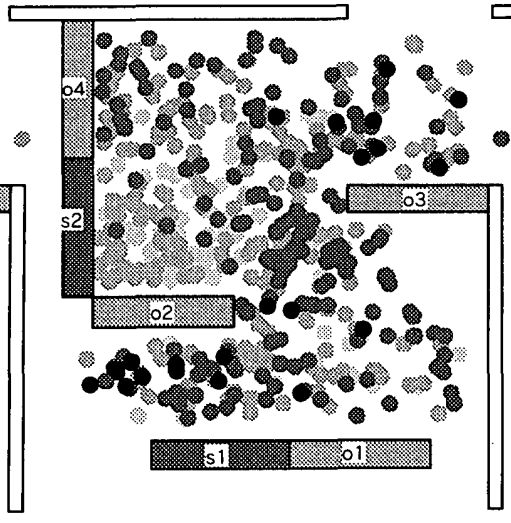

(b) 湿度分布

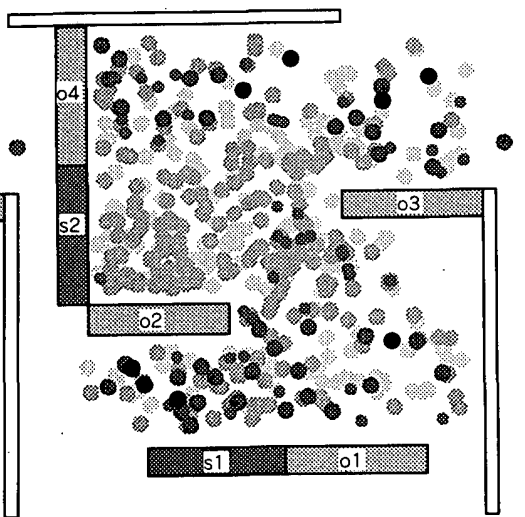

(c) 風速分布

図一8 移動測定結果 $(1997.9 .7)$ 


\begin{tabular}{|c|c|c|c|}
\hline \multicolumn{2}{|c|}{ 実験空間内測定項目 } & \multicolumn{2}{|r|}{ 表一-4 境界条件 } \\
\hline 測定項目 & 測定装置 & 流入面 & $\mathrm{u} / \mathrm{ul}=(\mathrm{z} / \mathrm{z} 1) 1 / 6$ \\
\hline 外部乾湿球温度 & 通風式白金抵抗乾湿計 & & $\sigma \sqrt{\mathrm{u}}=0.15, \mathrm{~L}=0.4 \mathrm{z}$ \\
\hline 外部風向・風速 & 超音波風速計 & 流出面 & 自由流出 \\
\hline 空間内気温分布 & $0.1 \mathrm{~mm} \phi \mathrm{T}$ 熱電対 & 上空面 & free slip \\
\hline 空間内湿度分布 & 抵抗値変化型乾湿ポリマー & 地上面 & $\log$ law \\
\hline 空間内風速分布 & 熟式微風速計 & 構造物 & $\partial \mathrm{T} / \partial \mathrm{xi}=0, \partial \mathrm{H} / \partial \mathrm{xi}=0$ \\
\hline
\end{tabular}

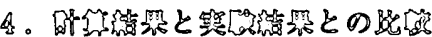

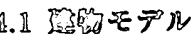

計算領域と差分格子を図-11 に示す。計算領域は、東西方向を $21.6 \mathrm{~m}$ 、南北方向を $22 \mathrm{~m}$ 、垂直方向を $7.6 \mathrm{~m}$ とした。格子点数は $57 \times 59 \times 25$ である。格子間隔は $0.2 \sim 1.0 \mathrm{~m}$ に变化する不均等メッ シュである。実際には、実験空間北側に、高さ $3.3 \mathrm{~m}$ のペントハウ スがあるが、ペントハウスを含めて解析を行うと解析領域が澎大に なり計算負荷も大きくなるため、ここではペントハウスを省略した 建物モデルで解析を行うことにし、実験結果との対応に関する考察 の際にはここで行った簡略化を考應する。

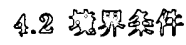

流入境界条件は、実験時の外部風速測定点の值から決定する。建 物屋上の風速に影梧を与える要因として 屋上周囲の手摺りや南西 側の山などが考えられるが、ここではそのような影㸷を受けた外部 風速測定点での風向・風速が、実験空間へ流入する風向・風速であ ると考えられる。よって、境界条件として解析領域の風上側流入風 速を実験時の屋外風向・風速測定点での測定点をもとに決定する。 (1)風速の流入境界条件

流入境界の風速は鉛直方向にべき分布を与えた。その際のべき指 数は、もっとも平坦なところでは 1/10～1/8で、粗度が増すにつれ て大きくなり、大都市中心では 1/3 1/2 で与えられる。ここでは、 建物屋上である程度開けた場所であるが、周囲の㚞林などの状況を 考虑して $1 / 6$ を与之、次式より流入境界風速を算出した。

$\frac{u}{u_{1}}=\left(\frac{z}{z_{1}}\right)^{1 / 6}$

ここで、 $\mathrm{u}_{1}$ は基準高 $Z_{1}$ における風速である。基準高は外部風 向・風速測定点の高さ $1.0 \mathrm{~m}$ とし、風速の測定值を $\mathrm{u}_{1}$ とした。 (2)乱流エネルギー $\mathrm{k}$ の流入境界条件

風速の変動成分の標準偏差 $\sigma_{\mathrm{u}} 、 \sigma_{\mathrm{v}} 、 \sigma_{\mathrm{w}}$ と平均風速 $\mathrm{u}, \mathrm{v}, \mathrm{w}$ との 比を乱れの強さとし、乱流エネルギー $\mathrm{k}$ は、この乱れの強さとべき 垂則の平均風速から等方性を仮定して次式より算出する。

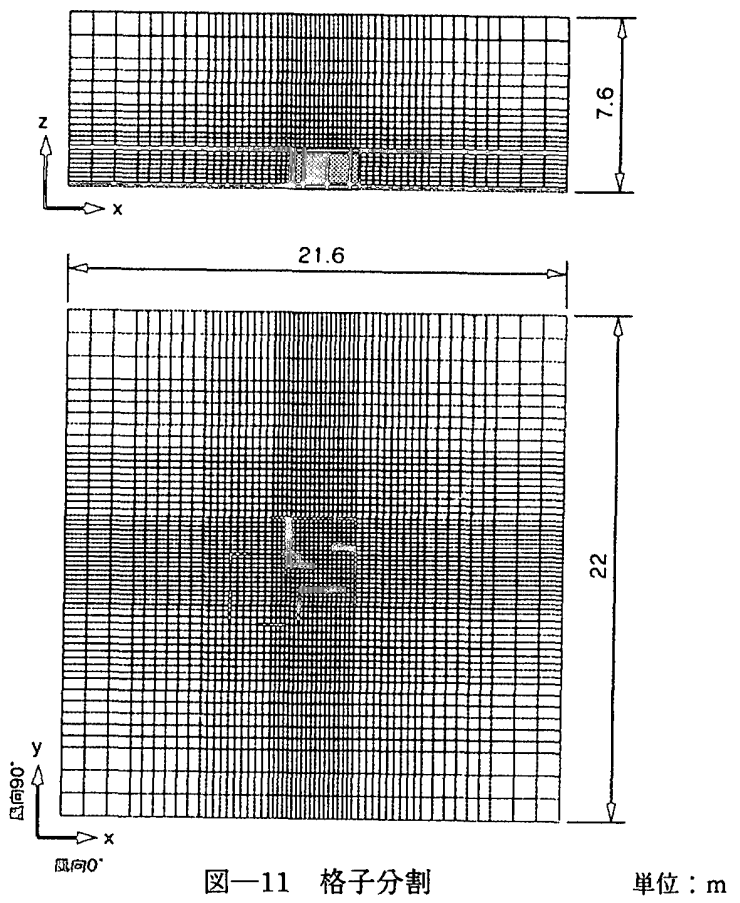




$$
\begin{aligned}
& \sigma u^{2}=\sigma v^{2}=\sigma w^{2} \\
& k=\frac{1}{2}\left(\sigma_{v}^{2}+\sigma_{v}^{2}+\sigma_{w}^{2}\right)=\frac{3}{2} \sigma_{u}{ }^{2}
\end{aligned}
$$

(3)乱流散逸 $\varepsilon$ の流入境界条件

流入境界においては渦動粘性係数 レ七を次のように与える ${ }^{8)} 。$

$\nu_{\mathrm{t}}=\mathrm{k} 1 / 2 \cdot \mathrm{L}$

ここで、Lは乱れの長さのスケールである。乱れの長さのスケール は接地気層内では地上面からの高さ $\mathrm{z}$ に比例するとして次式によ り与えられる。

$$
\mathrm{L}=0.4 \mathrm{Z}
$$

乱流散逸 $\varepsilon$ は (5.4) 式と（5.5）式と基礎方程式中の（2.7）式から 次式により算出する。

$$
\varepsilon=C_{D} \frac{k^{3 / 2}}{L}
$$

流入境界の温度は流入境界で乾球温度の値を一定值で与え、流入境 界の容積絶対湿度は乾湿球温度より算出した值を一定值で与えた。

(4)流出境界条件

上空境界においては Free slip 条件を、流出境界においては自由 流出条件を適用した。

(5)固体表面の境界条件

床表面及びウインドキャッチャー表面などの固体表面境界では 次式による対数則を適用し、風速、乱流エネルギー $\mathrm{k}$ 及び乱流散逸 $\varepsilon$ を計算する。

$\frac{u}{u_{\tau}}=\frac{1}{\kappa} \ln \left(\frac{u_{\tau} Y}{\nu}\right)+B$

ここで、 $\mathrm{u}_{\tau}$ は摩擦速度、y は壁面との距離である。また、カルマ ン定数 $\kappa$ は 0.41 としBは 5 とした。温度と水蒸気量については、 各物理量の固体表面の法線方向の勾配を 0 とする条件とした。

(6) P C Wの境界条件

P C W 部分については、レンガ表面を完全飽和であると仮定する とレンガ全体を外気湿球温度に等しいと見なされる2)。よって、基 礎方程式中の (2.5) 式におけるレンガ表面温度 T p cw は外気湿球温 度とした。（2.6）式中のレンガ表面湿度 $\mathrm{X}$ pcw もレンガ表面を完全 飽和であると仮定して算出した。また、レンガを通過した風速はレ ンガの放線方向以外の成分が 0 となると仮定して境界条件を設定 した。

\section{3 解析モテルによる即算塻果}

結果の一部としてケース 1-2 の例を図ー12 に示す。

(1)気温分布

s 2、o 2 に囲まれた部分の温度が低くなっており、南西側の開 口部の温度は高くなっていることが分かる。高さ $0.3 \mathrm{~m}$ では、 P C $\mathrm{W}$ 近傍で低温空気の下降がみられるものの、低温領域の広がりは高 さ $1.0 \mathrm{~m}$ の方が大きいことが分かる。

(2)湿度分布

気温が低下する部分で湿度が上昇するといった、いわゆる蒸発冷 却による微気候の特徵が良く現れている。また、外気の流入により 南西側開口部付近で湿度の低い部分が形成されている。

(3)風速分布

s 2 ，。2 に囲まれた部分で風速が弱く、P C Wによる風速の減 衰がみられる。また、南西側開口部と北東側開口部では風速が強く
なっており、外気の流入部と流出部で風速が上昇する様子が現れて いる。

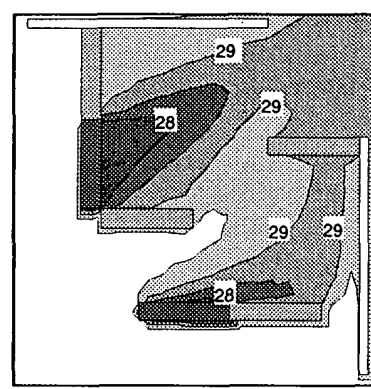

気温分布 $1.0 \mathrm{~m}\left({ }^{\circ} \mathrm{C}\right)$

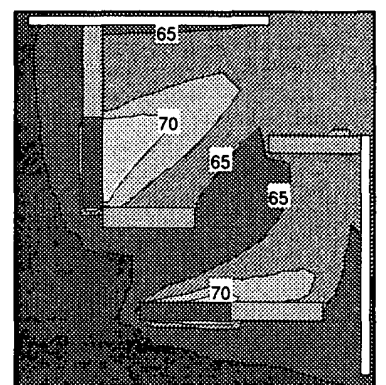

湿度分布 $(\%)$

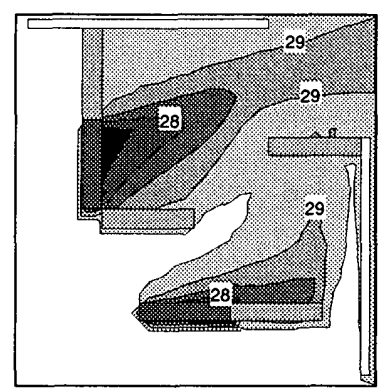

気温分布0.3m( $\left.{ }^{\circ} \mathrm{C}\right)$

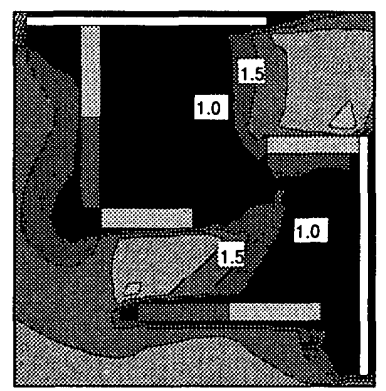

風速分布 $(\mathrm{m} / \mathrm{s})$
図-12 計算結果（ケース 1-2）

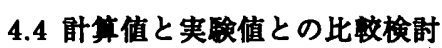

計算値が実験值とどの程度、対応がとれているのかを検討するた め、全ケースの計算值と実験值を温度（高さ 0.3 及び $1.0 \mathrm{~m}$ ）、湿 度及び風速のそれぞれについて比較した。図一13 に計算値と実験 値の散布図を示す。

(1) 気温

高さ $1.0 \mathrm{~m}$ の気温では、計算值が全体的に $1.0^{\circ} \mathrm{C}$ 程度高くなって いるが、これは解析モデルが P CWの孔の扱いとして抵抗係数、熱 伝達俰数を 1 次元で扱ったことによる影響、SIMPLE 化による計算 の影響などが原因として考えられる。しかし、空間全体の分布とし

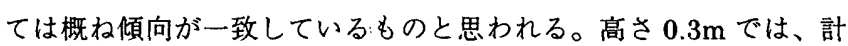
算値が $1.0 \mathrm{~m}$ と比較して全体的に低く計算されており、Viollet 型の モデルの特徴が示されている。しかし、上記のような解析モデルの 孔の扱いによる誤差が同様に認められる。さらに、実験時の。1と s 2 の下部が乾燥しており表面温度が若干高くなっていた影響で 点 $2 、 10 、 11 、 16 、 17$ (線で囲まれた部分) では実験値の方が高 くなっている。

(2)湿度

全体的な空間の性状として、気温の低い部分は湿度が高く、気温 の高い部分は湿度が低く計算されており、P CWの特徴が示されて いる。気温と同様に計算值が SIMPLE 化による影響などから完全 に一致するものではないが、分布の傾向は概ね対応している。

(3)風速

全体としてあまり対応がみられない。北東開口部付近の風速が大 きく、点 $18 、 24 、 25$ の計算値が高くなっているが、これは実験空 間北側のペントハウスを無視して計算したためだと考えられる。ま 
た、解析モデルでは有効体積率を考慮しておらず、孔内の風速上昇 が再現されていないため、P C W近傍の点 19 で計算值の方が実験 值より小さくなっている。さらに、PCWの扱いを1次元で行った ことや計算の簡易化による影響がこのような結果として現れたも のと考えられる。

व $4 \circ 2 \Delta 3 \times 4 \times 5 \circ 6 \circ 7+8 \square 9 \circ 10 \Delta 11 \circ 12 \circ 13 \circ 14$ $\Delta 15 \times 16 \times 17-18: 19+20 * 21 \otimes 22 \& 23 * 24 \oplus 25$
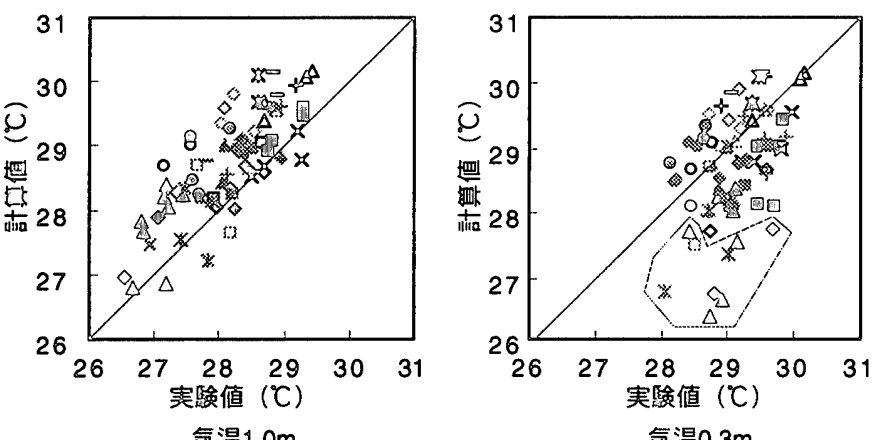

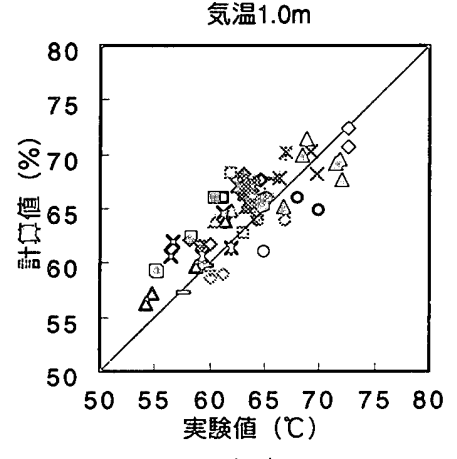

湿度

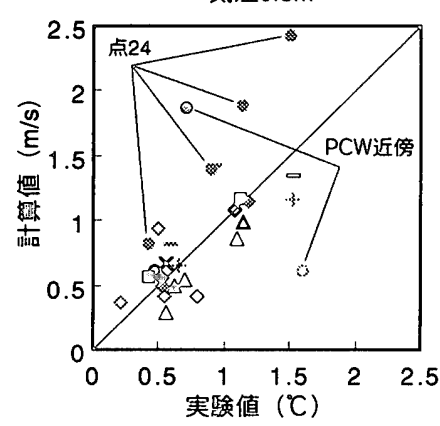

風速
図一13計算値と実験值の比較結果

5.茫と的

本研究では、P C Wにより形成される気候分布を簡易に予測でき る手法を開発することが設計の際の有効なッールになると考え、微 気候の空間的性状を屋外実験によって把握するとともに既往のモ デルを応用した解析モデルを作成し、風向風速が一定条件のもとで の計算結果と実験結果を比較して、本予測手法の有効性について検 討した。得られた知見を以下に示す。

（1）蒸発却機能を有する孔あきレンガ壁体により形成される気候分 布を簡易に予測するため、平岡らの $\mathrm{k}-\varepsilon 2$ 方程式モデルに $\mathrm{P} \mathrm{C} \mathrm{W}$ 特有の抵抗、蒸発、冷却機能を付加した解析モデルを作成した。 (2) 屋外実験により、PCWにより形成される微気候の空間的な性 状を把握するとともに、解析モデルの計算結果との対応について比 較検討を行うために風向・風速が安定していた期間を抽出して、定 常的なデータとして取り扱えるように考跑した比較用実験データ を整理した。

(3)計算結果を実験結果と比較した結果、気温、湿度の分布に関して はモデル化の際の P C Wの孔の扱いや計算方法の簡易化の影響が 見られるものの概ねその傾向には对応が見られた。風速に関しては 上記理由に加え、有効体積率をモデルに導入しなかったことが原因 と思われる不一致がみられた。
6. 3 放りに

本研究では、P C Wを用いた屋外空間デザインの設計支援手法と して、樹木廻りの気流解析で検討された圧力損失項の組み込み方法 を適用した場合、本研究で扱ったような限られた条件下ではある が、実験結果と概ね同様の傾向を予測することができ、実際の設計 の際の有効な手法として適用できる可能性を示唆したものと考え る。しかしながら、微気候の把握という点では、平均流を扱う $\mathrm{k}-$ $\varepsilon$ モデル自体の問題をはじめ、P CWの抵抗係数、熱伝達係数の孔 あき流通方向以外の扱い、有効体積率の問題など更なる検証が必要 であり、今後の課題とする。

说笘

本研究を実施するにあたり、解析モデルの作成においては東京工 業大学教授田村哲郎先生より貴重なご助言を頂いた。ここに記して 感謝の意を表す。

注

1） 3 次元位置測定装置とは、ある空間内の任意の場所における温度、湿度、 風速測定を行い、同時にその測定位置を電磁波による信号で把握するものであ る。これにより、ある範围内での移動観測が可能となる。

2) 本論文は、1998 年度日本建筑学会大会（九州）にて発表した内容（D-2 環境工学I、pp.709-711）を加筆・再編集したものである。

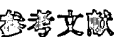

1)白井一義、梅干野昆、堀口剛：透水性孔あきレンガを用いた蒸発冷却壁体の 開発、日本建築学会計画系論文集、第 487 号、PP61-68、1996.9 2)白井一義、梅干野鼠、永田達也、小栗健：透水性孔あきレンガの通気孔形状 と通気・冷却性能の関係透水性の孔あき壁体を利用した蒸発冷却による屋 外・半屋外快適空間の形成その 1、日本建築学会計画系論文集、第 509 号、 pp9-14、1998.7

3)吉田伸治、村上周三、大岡龍三ほか：対流・放射·湿気連成解析による屋外

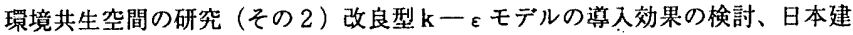
等学会大会学術講演梗概集（九州）、pp937-938、1998.9

4)白井一義、梅干野昆、永田達也、小栗健 : パッシブクーリングウォールの半 屋外筀間における徽気侯形成効果透水性の孔あき壁体を利用した蒸発冷却 による屋外・半屋外快適空間の形成その $2 、$ 日本建築学会計画系論文集(採用決 定)、2000.1

5)平岡久司ほか：植物群落内および都市キャノピー内での乱流モデルの考察、 第 3 回生研 NRTシホボジ弘講演御文集、東京大学生産技術研究所 NST 研究グル ープ、pp87-93

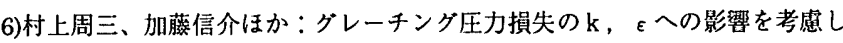
た改良型 2 方程式モデル、空気調和・衛生工学会学術講演会講演論文集、 pp717-720、1988.9

7)平岡久司ほか：植物群落内および都市キャノピー内での乱流モデルに関する 研究（その 1 ）乱流モデルの作成、日本建筑学会計画系論文集、第 406 号、 1989.12 8)数值流体力学編集委員会編: 乱流解析 数值流体力学シリーズ $3 、$ 東京大学出 版会、 1995.7

（1999年 7 月10日原稿受理，2000年 1 月11日探用決定） 